IRSH 48 (2003), pp. 40I-426 DOI: I0.I0I7/So02085900300II 35

(C) 2003 Internationaal Instituut voor Sociale Geschiedenis

\title{
Disgruntled Guests: Iranian Subaltern on the Margins of the Tsarist Empire*
}

\author{
Touraj A TAB AKI
}

Summary: The present essay studies the Iranian migrants residing on the margins of the Tsarist empire. The article deals with the social forces causing migration; the formation of the Iranian subaltern community in the Caucasus; the community's social structure (gender, ethnicity and age); the migrants' working and living conditions; and their political culture.

Every year throughout spring in the mountains on the frontier you could see thousands of poor and ill-fated Iranians barefoot and in tattered clothes, in groups of forty to fifty, illegally crossing the borders of the Empire in search of work. Any attempt to hinder this labour passage would have a devastating effect on our booming economy.

Extract from a report compiled by the governor of Elizabethpol in I 887

Suffering from two consecutive military defeats by the expanding Tsarist Empire in I8I3 and I828, Iranian society went through gradual but significant political as well as socio-economic transformations. One of the ultimate consequences of these gradual transformations was a series of major social dislocations in Iranian society. Urbanization and migration to neighbouring countries in pursuit of work or political shelter were the vivid manifestation of such social dislocations. The migration of Iranian subaltern and political activists began in the mid-nineteenth century. ${ }^{\mathrm{I}}$ Imperial Russia, India, the Ottoman Empire, and north and west Africa were the most favoured destinations for the Iranian migrants. Of these

\footnotetext{
For their comments and suggestions regarding this article I would like to thank Hans Timmermans, Ulla Langkau-Alex, and Marcel van der Linden.

I. My usage of the term "subaltern" is based on the description given by Gramsci in his The Modern Prince and The Prison Notebook. According to Gramsci, the subaltern classes are those subordinated by hegemony and excluded from any meaningful role in a regime of power. Although Gramsci himself had workers in mind, the term was later used to describe other groups who are excluded and do not have a position from which to speak. See Antonio Gramsci, Prison Notebooks (New York, 1992), and idem, The Modern Prince, and Other Writings (New York, i967).
} 
destinations, the margins of the Tsarist Empire, the Caucasus and Central Asia were the favourite constituencies for the people of central and northern Iran. The flourishing economy of the nineteenth century and the relatively liberal political setting of the Caucasus and Central Asia attracted many Iranian migrants. The economic and political migration of Iranians to this region gradually became the major migration trend in nineteenth-century Iran, and by the time of the Russian Revolution of I9I7 hundreds of thousands of Iranians had settled throughout the southern districts of the Tsarist Empire. Throughout the Caucasus region these Iranian migrants, most of whom came from Iranian Azerbaijan and lived in the Caucasus amongst their co-ethnic and co-linguistic group, were known as hamshabri [fellow countryman], and they maintained a separate sense of identity which marked them out from the local population to the north of Iran's frontier.

Although the life and times of the Iranian migrants at the margins of the Tsarist Empire during the nineteenth century have been the subject of a number of academic studies, the need for a new inquiry still seems well founded. One reason is that since the demise of the Soviet Union the archives of the Soviet as well as of the Tsarist period have become more accessible. Furthermore, in the past ten years the availability of archival documents, especially those relating to the Qajar and early Pahlavi periods in Iran, has added significantly to our understanding of the nineteenth-and early twentieth-century history of the region.

Another reason for a new inquiry stems from the quality of previous studies. The historiography of the Russo-Iranian connections suffers to a large extent from essentialist deficiencies. One example is the question of Iranian migration to the Tsarist Empire. By reducing the forces causing the migration to an economic motive, the dominant historiography denies the existence of other social and political incentives to migration. By closely studying the history of Iranian migration, one might also conclude that throughout the long period of the nineteenth and early twentieth centuries there were times when, notwithstanding constant nonlinear economic factors, other factors became more decisive in driving people to the north. The study of the causes of migration is not the only field where such reductionism is so vividly marked. In studies of the life of the Iranian migrant community in Imperial Russia the essentialist approach denies, by highlighting notions such as class and class solidarity, the existence of other sets of solidarities massing people together and driving them to fill the vacuum between their origins and their actuality.

By examining the scale of the migration and the living conditions of the Iranian subaltern residing on the margins of the Tsarist Empire, this article will present an overview of political developments within this community in the Caucasus in conjunction with political changes both in Iran as well as in the Caucasus. 


\section{FORCES CAUSING THE MIGRATION}

Iranian society's reaction to the military defeats of the early nineteenth century was a precipitous endeavour to introduce a series of changes and reforms throughout the country. Although it was initially the political elites, both inside as well as outside the political establishment, which were calling for changes and reforms, it soon became a public plea joined by the country's merchants, craftsmen, and urban wage earners. The messianic Babi movement of the I 840 s was the grand manifestation of this popular demand. Within a few years, the Babi movement had mobilized an amalgam of different but discontented urban social classes, as well as some rural groups. ${ }^{2}$ As will be shown later, although the brutal suppression of the Babi movement put an end - at least for the next forty years - to any endeavours to implement reform from below, the ruling political elites nevertheless continued with their reformist agenda from above. Gradually, it changed the political features of the country - guiding it towards the Constitutional Revolution of I905-I9II.

The political concessions, commercial capitulations, and economic penetration that were the direct consequences of the military defeats led the Iranian economy to become more dependent on the international market and its fluctuations. The decline of the domestic and external value of the Iranian currency, the increase in the level of the country's foreign trade, the commercialization of agriculture and the decline in non-export agricultural products and the traditional crafts and local industries, the rise in the production of cash crops, and the gradual increase in the country's population from five or six million in I 800 to about ten million in I9I $4^{3}$ resulted in class dislocation and population displacement. ${ }^{4}$ Such changes brought a new pattern of consumption and subsequently changed social norms, social stratification, and the traditional power structure. This pattern of change was intensified further in 1869 by the excavation of the Suez Canal, which provided easier access to the Indian Ocean for European navigation. At the same time, the importance of the TabrizTrebizond route diminished. The closure of this route, which for centuries had been the most important route joining Europe to the Indian subcontinent, was an extra burden for the Iranian economy, which was already going though a drastic decline, creating massive unemployment.

During the nineteenth century, Iran suffered from outbreaks of famine more often than during any century before. The main cause of the famine was the loss of the country's "grain store". For centuries, the agricultural lands north of the Araxes river, especially the Nakhjivan region, were

2. For a detailed study of the Babi movement see Abbas Amanat, Resurrection and Renewal: The Making of the Babi Movement in Iran, I844-I850 (Ithaca, NY, I989).

3. Charles Issawi (ed.), The Economic History of Iran I800-I9I4 (Chicago, IL, I97I), p. 20.

4. Homa Katouzian, The Political Economy of Modern Iran (London, I98I), p. 27. 
providers of grain for northern and central Iran. The annexation of the region by Imperial Russia not only deprived Iran of its "grain store", the manpower working on the land was also lost. However, there were also other reasons for the famine. The famine of I 859-i 860, for example, was caused by the export of grain to Russia, which was followed by social disturbances and an increase of between 70 and 400 per cent in the price of all essential supplies. ${ }^{5}$ Famine once more swept through Iran in I 87 I-I 872 and r895-i 896. Both of these famines were caused by local magnates hoarding grain.

In Iranian Azerbaijan and the provinces of Isfahan and Khorasan, the cyclical bread shortages of the i 870 s to the I890s, which were mainly caused by local governors hoarding grain, caused a massive influx of refugees from some provincial cities. As a result of the widespread official practice of closing all the city gates during an economic crisis to prevent the influx of refugees, the only option left for displaced people was to cross the border illegally into neighbouring countries. According to a report by the French consul in Tabriz, in I895

$[\ldots]$ the shortage of grain, which for some years has caused serious political unrest in the province, was mainly the result of the corrupt conduct of the local governor. By gradually purchasing all the province's farming land and hoarding the grain for selling at higher prices, the governor created a disastrous economic crisis in the province. ${ }^{6}$

The people's failure in their petition to the central government to secure intervention in their favour paved the way for mass migration and urban as well as rural riots. After months of confrontation, these riots only eased once grain entered the market. ${ }^{7}$

With the decline of the traditional economy and the limited potential of the new economy to provide occupations for thousands of working men in their traditional locality, leaving rural areas for the cities in pursuit of jobs gradually became a new trend. However, with cities having only limited potential to provide jobs and shelter to the newcomers, and often having closed their gates to immigrants anyway, the regions beyond the borders became the most prominent alternative calling the Iranian subaltern.

The practice of arbitrary rule at each and every level of public life had always been a force behind migration throughout Iranian history. Nevertheless, if in the presence of a strong and effective government the exercise of arbitrary rule at the provincial level by local governors and tribal chiefs was somehow checked by the central government, in the

5. Abbas Amanat, Pivot of the Universe, Nasir al-Din Shab Qajar and the Iranian Monarchy I 83 I-I896 (London, I997), pp. 204-2 I I.

6. French consulate report, Tabriz to Paris, 7 August I 895. Quoted in Homa Nategh, Karnameb va Zamaneh Mirza Reza Kermani (Bonn, 1984), p. I17.

7. Ibid., p. I 20. 
nineteenth century - with the country's economy in decline and the weakening of central control over the provinces - the practice of arbitrary rule was incontestably extended throughout the country. The enduring incursions and looting of villages in northwest Iran by Kurdish tribes during the nineteenth century forced tens of thousands of peasants, especially the Christians (mainly Armenians and Assyrians), to leave Iran for Imperial Russia. According to Nafisi, during the first half of the nineteenth century more than 60,000 Christians left Iran. ${ }^{8}$ In addition to the threat from local tribes, one should also consider Russia's far-reaching Christian repatriation policy in the region, which encouraged the Iranian Christian community to move to the southern constituencies of Tsarist Russia. ${ }^{9}$ In Iran, the Christian community was subjected to a range of discriminatory policies, including having to pay a different poll tax. But in introducing "Caucasus development planning" the Russian authorities exempted the new migrants from paying taxes during the first two years of their arrival in Imperial Russia. ${ }^{\circ}$

The discriminatory economic policy towards the Christian community was not the only factor causing religious minorities to opt for migration. Another and more serious factor was religious persecution, and especially the uninterrupted harassment of the Babis. The mass persecution of Babis in the second half of the nineteenth century, especially after the failed attempt on the life of the Qajar king, Nasser al-Din Shah in I $852,{ }^{\mathrm{II}}$ added to the influx of migrants to the north. The persecution and the gruesome slaughter to which the Babis were condemned was a signal to the populace, whether sympathetic to the Babis or not, of the consequences of challenging the existing order - a spectacle to remind as well as to avenge. ${ }^{12}$ According to one chronicle,

At Milan, a village near Tabriz [in northern Iran], a large number of the inhabitants had been converted to the religion of the Bab. Following the attempt on the life of the Shah, a group of government servants and soldiers came from Tabriz and fell upon the helpless Babis of the village and sacked their houses. A number suffered martyrdom immediately while a further group were taken to Tabriz. ${ }^{13}$

During the following years, Ashgabat and Baku, on the southern frontiers of Imperial Russia, provided shelter for thousands of Babis fleeing from

8. Said Nafisi, Tarikh-e Ejtema'i va Siyasi-e Iran dar Doreb-e Mo'aser, vol. 2 (Tehran, 1961), p. I43.

9. Homa Nategh, Iran dar Rabyabi-ye Farhangi (London, I988), p. I6r.

Io. Ibid.

I I. For a detailed account see Amanat, Pivot of the Universe, p. 382.

I2. Ibid., pp. 21 2- 213.

13. Moojan Momen (ed.), The Babi and Bahai Religion 1844-1944: Some Contemporary Western Accounts (Oxford, I981), p. I45. 
subjugation in their home country. While Baku, with its dominant Shiite Muslim population and with a strong link to the Iranian clerical Shiite hierarchy, was considered a less favourable destination, Ashgabat, with its dominant Christian population, proved to be a safe haven, where the Babis were able construct their own places of worship.

Finally, in studying the economic and political forces behind Iranian migration to the north, one should also consider the economic and political changes that swept Russia during the nineteenth and early twentieth centuries. Russia's strong state-oriented policy of industrialization, and the development of massive mining projects and expansion of domestic industries, led to an apparent labour shortage in Russia. By adopting a policy of importing the labour force it required, Russia aimed not only to supply the manpower it needed for its labour-intensive industries but also for the expanding agricultural lands and industries, including its tea plantations. This policy certainly appealed to many of its neighbouring countries, including Iran.

In the political sphere, one of the major consequences of the annexation of the Caucasus to the Tsarist Empire was the consolidation of ethnic solidarity amongst the Georgians, the Azeris, and the Armenians. The public desire for independence gradually became one of the main engagements of the new educated middle class within each of these ethnic communities. By the end of the nineteenth century Georgian, Azeri, and Armenian nationalism held sway over the southern Caucasus. Moreover, the political changes in Russia also affected everyday life in the Caucasus. In the second half of the nineteenth century the Caucasus became one of the most important backyards of Russian revolutionary and reformist organizations. For many politically minded Iranians, the Baku and Tbilisi of the late nineteenth century were cultural magnets where they could become acquainted with new ideas and practice their aspirations. Living in such a political environment refashioned their political consciousness and made their contribution to political change in their homeland more vivid.

The political changes and upheavals too, both in Russia and Iran, had an effect upon the number of migrant subaltern. For some years the RussoJapanese war of the early twentieth century, which was followed by the Russian Revolution of 1905 , and the Iranian Constitutional Revolution of I905-I9I (as we see in the following pages) hindered the process of migration to the north (see Figure 3). Moreover, although the Iranian government benefited directly from the income the migrant subaltern returned to the country, there were nevertheless occasions when the number of migrants reached such high levels that the government endeavoured to hinder migration, mainly by diplomatic negotiations and ratifying protocols with Russia demanding that the latter refuse to accept new migrants. However, migration was too strong a force to be stopped by diplomatic treaties. 
The Iranian migration to the Caucasus dates back to the early nineteenth century. Prior to this period, the southern Caucasus Khanates, although they enjoyed extended autonomy, nevertheless still considered themselves part of the Persian Empire. With the endorsement of the Gulestan and Turkmenchay treaties of 1813 and 1828 , the people of the region were separated from each other along the political borders dividing Iran from Russia. The annexation of the southern Caucasian region forced the subjects of thirteen Khanates to accept citizenship of Tsarist Russia. They were mainly Georgians, Armenians, and Azeris. The most significant of these groups were the Azeris, or, as the Russians called them, the local Tatar, who lived along the Araxes river. While the status of the northern Azeris was changed - they accepted citizenship of the Tsarist Empire the people south of the Araxes river remained within the realm of the Persian government and retained their Iranian citizenship.

The annexation of the southern Caucasus to the Tsarist Empire had farreaching consequences. For centuries, people in this region used to travel freely up to the Black Sea. Now, with the imposition of a new border between the two countries, people on both sides of the Araxes river had to cross a border that had been drawn without their consultation. Regardless of the many attempts by both countries to formalize the travellers' movement across this new border, the problems relating to the border and border crossing remained a major concern for both countries. In the early years of annexation, Tsarist Russia endeavoured to counter the mass migration and illegal crossborder trafficking by introducing new laws and regulations. Iranians wanting to cross the border were required to obtain visas from Russian consulates within the border provinces. On arrival in Russia, they were also asked to register with the local authorities and obtain residence permits.

With the Iranian economy in gradual decline during the nineteenth century, the flourishing economy of Russia had been attracting many Iranian subalterns. They moved, in search of work, by different routes, legally or illegally to the southern region of the Tsarist Empire, especially the Caucasus. The influx of these seasonal and nonseasonal labourers gradually reached such high proportions that it eventually became a cause of great unease to the Iranian government. The Iranian government's apprehension was demonstrated noticeably in the Treaty of I 844 signed between the two countries. Amongst other issues, what was significant in this agreement was the influx of Iranian subjects into Russia and the guarantee of Russian citizenship offered them by the Tsarist authorities. Under this agreement, those Iranians intending to adopt Russian nationality had to obtain the Iranian government's written permission. 
On the other hand, although the Russians were eager to formalize the existence of their new border with Iran, as far as migration was concerned they adopted their own agenda and continued their policy of importing labour when required. According to an article in the journal of the Ministry of Internal Affairs of the Tsarist Empire, published in I845, "there was a huge arrival of Iranian and Ottoman masons and carpenters in the southern Caucasus and they somehow monopolized the local labour market". ${ }^{14}$ According to another source, in 1858 a total of 4,852 passports were issued to those crossing the Russian-Iranian frontier in search of work in Tbilisi, Elizabethpol, Shusha, Shamakhi, Yerevan, and the other southern Caucasus cities. ${ }^{\text {IS }}$ The number of passports issued corresponds to the number of migrants who crossed the border legally. The long natural border between the two countries provided many possible routes enabling illegal migrant workers to avoid the eyes of the eager border guards. Although there are no statistics available, the number of illegal migrants would definitely have exceeded the number of legal migrant labourers. ${ }^{16}$

The free exploitation of the oil deposits in the Apsheron peninsula on the Caspian coast in I 872 caused the mass migration of Iranian labourers to the Caucasus and central Asia. The rapidly growing oil production of the Caucasus soon elevated the region to supplier of 95 per cent of all Russia's consumer oil and holder of the second largest oil deposits in the world, after the United States. Along with the British, French, and German companies operating in the region, it was the Russian state capital that anticipated benefiting from underground resources in a territory which, on the eve of its occupation and annexation, was considered of solely geopolitical and military importance.

The strong Russian state-oriented industrialization policy of the late nineteenth century paved the way for a massive expansion of domestic industries, the development of huge mining projects, and a dazzling extension of railway networks into the southern regions of the Tsarist Empire. ${ }^{17}$ The construction of roads and railways such as the TransCaspian network, connecting the Caucasus with central Asia, increased labour migration and resulted in an even greater population dislocation, as well as the expansion of the ancient cities and the building of new industrial zones. Baku is one such example: as a result of the "oil rush", its population rose from I 3,000 in I 859 to I I 2,000 in I 879 and to 300,000 in 1917. Another is the workforce in the oilfields, which rose from I,800 in I 872 to 30,000 in $1907 .{ }^{18}$

I4. N.K. Belova, "Ob otchodnichestve iz severozapadnego Irana v kontse XIX- nachale XX veka”, Voprosy istorii, , $о$ (1959), p. I I 2.

Is. Ibid.

16. Ibid.

I7. M.E. Fakus, The Industrialisation of Russia, I700-19I4 (London, I972), pp. 44-46, 64-66.

I8. Encyclopaedia of Islam, CD-Rom edition (Leiden, I999). 


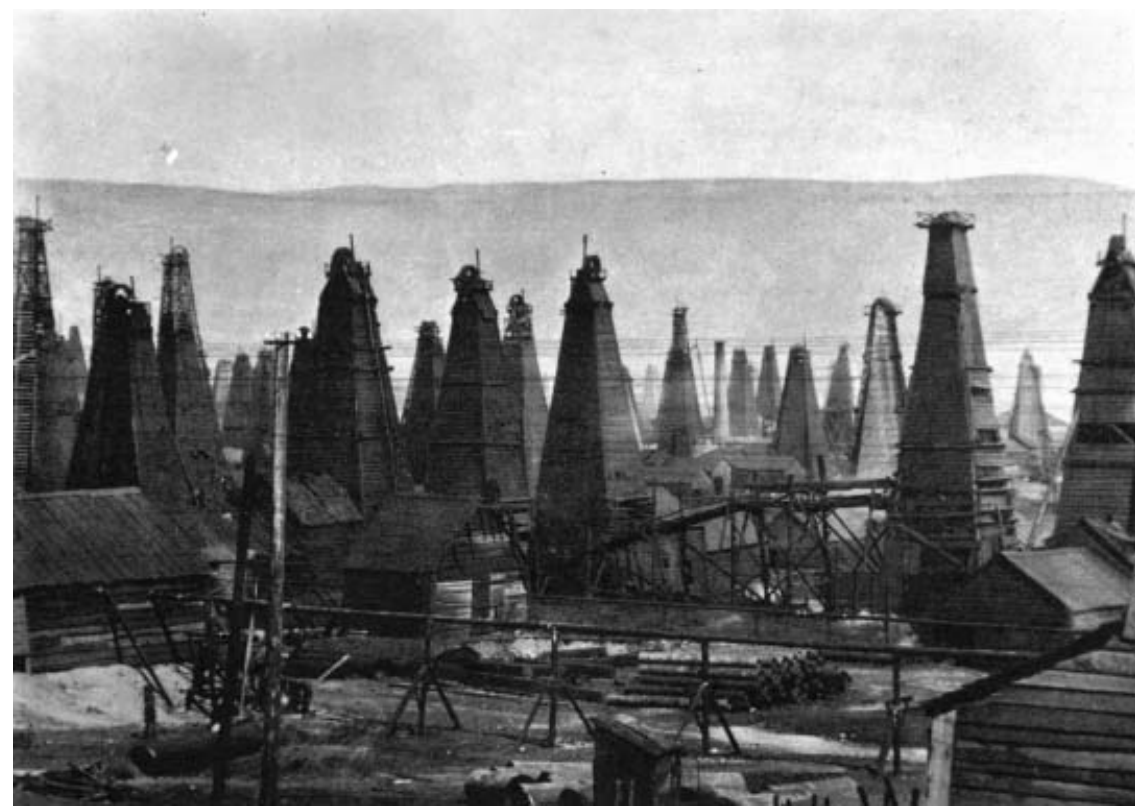

Figure I. Bibi-Eibat oil field.

From: A. Beeby Thompson, The Oil Fields of Russia and the Russian Petroleum Industry: A Practical Handbook on the Exploration, Exploitation and Management of Russian Oil Properties (London, I908), facing p. IIO.

In such an increased tempo of economic activity, labour shortages soon became evident. It was not only labour-intensive industries that faced serious shortages; the expanding agricultural lands and industries were also affected. Consequently, along with local people, hundreds of thousands of Russians, Armenians, and Dagestanis migrated to mining areas and the oilfields, as well as to other industrial regions. Nevertheless, many branches of production in Russia still faced severe labour shortages, and the import of foreign labour turned out to be the first task for the Russian authorities in the region. ${ }^{19}$ It was believed that nineteenth-century Iran with its declining economy and outstretched border with Russia - could supply the cheap labour needed for the fast-growing Russian economy.

Although a large proportion of the Iranian migrant subaltern went to the southern Caucasus, the number of migrants seeking work in the various parts of central Asia was also significant. In addition to using the perilous route that passed the Turkmen desert, there is information showing that 
migrant workers reached central Asia by way of Transcaucasia. For example, in I 886 Nikolskii, in an account of his travels, reported that "In Baku our ship took on three hundred Iranian workers, on their way to work on the Trans-Caspian railway." ${ }^{\circ}$ Consequently, within ten years the number of Iranians in Central Asia rose from 23, 19I in I 897 to 55,000 in I907, and they became the main immigrant community in the region. ${ }^{2 \mathrm{I}}$

The Iranian migrants resided in various places in the Russian Empire: Baku, Yerevan, Tbilisi, Elizabethpol, Batum, Astrakhan, Ashgabat, Marv, Samarkand, the northern port cities of the Volga, and also in the less important industrial centres, such as Alaverdi and Nukha. In 1885 , in a memorandum addressed to the Russian Ministry of Foreign Affairs, the Russian government commissioner in charge of immigration to the Caucasus raised the issue of guaranteeing Russian citizenship to thousands of Iranian labourers who had migrated to Russia prior to i 870 . The Ministry of Foreign Affairs responded positively, but in a communiqué dated I7 March I886 it was mindful of the 1844 Russian-Iranian agreement on cross-border issues - which prevented either country from guaranteeing citizenship to subjects of the other country - and underlined the "need for further vigilance in dealing with the scheme and to accomplish it in absolute tranquillity". ${ }^{22}$ Meanwhile, as regards the possibility that Russia's citizenship practices might eventually be revealed, the communique urged the Russian representatives in Iran to claim that, in the event of a possible protest from the Iranian government, the Iranian authorities must themselves "be held responsible for their incompetence in controlling their own northern frontiers". ${ }^{23}$

As expected, the Iranian government gradually became concerned by the mass migration of the Iranian subaltern to Russia, and on more than one occasion it approached the Tsarist government's representative in Tehran to ensure mutual cooperation in order to extradite thousands of Iranian emigrés living on Russian soil. In I 886, in a letter to the governor of Baku, the Russian government commissioner in charge of immigration to the Caucasus urged the governor [while] "considering the Empire's economic interest, [to] apply appropriate measures in order to diminish the tension between the two governments". ${ }^{24}$ Accordingly, the governorship of Baku decided to deport some of those migrant Iranian subaltern who had settled in Russia after I870 and were employed in the marginal sector of the province's economy. Hundreds of migrant workers were

20. A.M. Nikolskii, Letnie poezdki naturalista (Leningrad, I924), p. I29.

2 I. A.Z. Arabadzian and N.A. Kuznetsova (eds), Iran. Sbornik Statei (Moscow, 1973).

22. Republic of Azerbaijan State Central Archive [hereafter, RASCA], record 44, dossier I, file 45 , p. 3 .

23. Ibid.

24. Ibid. 
expelled in groups of 50 to 100 , while the authorities refused to allow them to take their personal possessions with them. ${ }^{25}$

While by such diplomatic gestures the Tsarist government endeavoured to demonstrate its commitment to bilateral agreements with Iran, it never closed its border to the influx of cheap labour from its neighbour. Local landowners, oil companies, and industrialists were hostile to the government adopting any measures hindering the immigration of Iranian labourers. According to the governor of Yerevan, "any measure to limit the migration of the Iranian labourers could result in disastrous shortages of manpower in the region". ${ }^{26}$ As a result, the Russian government issued a new law in I 887 allowing the Iranians to reside in the Russian border provinces for a maximum of six months without the need for appropriate permission or visas. A year later, this was extended to other provinces and included all of Russia. According to an official report, in I 889 there were thousands of Iranian labourers in the Caucasus who had neither an official work permit nor an entry visa. ${ }^{27}$

Towards the beginning of the twentieth century, the rapid influx of Iranian subaltern crossing Russia's frontiers was constantly increasing. Russian consulates in Persia, especially in the northern provinces of Azerbaijan, Gilan, and Khorasan, issued work permits and visas to thousands of Iranians wanting to leave their country in pursuit of work. Documents from the Russian consulates in the northern frontier cities of Tabriz, Mashhad, Rasht, and Astarabad indicate that between I876 and I 890 an average of I3,000 Iranians per year acquired work permits and visas to enter Russia legally. By I 896 this figure had reached 56,37I. The number of work permits issued by the Russian consulate in Tabriz rose from I 5,6I5 in I 89 I to 32,866 in I 900 - an increase of I Io per cent in 9 years. ${ }^{28}$ In the province of Khorasan, the influx of people seeking "work in the Transcaspian region in 1909 increased so fast that the number of villages with offices for granting external passports rose from ten to twenty-five". ${ }^{29}$ In 1904, the number of visas issued to Iranian migrant labourers reached a total of $71,407,3^{30}$ and 7 years later, in I9I I, of a total of I 92,767 labourers entering Russia legally I60,2 I I were Iranians. ${ }^{3 \mathrm{I}}$

However, one should realize that these figures do not cover those migrant workers who crossed the frontier illegally. If one recognizes that in nineteenth-century Iran crossing the frontier was common practice

25. Ibid.

26. RGSCA, record I 3 , dossier I, file 267 , p. I6.

27. RGSCA, record I I, dossier 4, file 3104, pp. 38-39.

28. V. Miller, Dvizhenie persidskikh rabochikh v Zakavkaz'e. Sbornik konsul'skikh donesenii Ministerstva Inostrannikh Del, vol. 3 (St Petersburg, 1903), p. 205.

29. Issawi, The Economic History of Iran I800-1914, p. 52.

30. Miller, Dvizhenie persidskikh rabochikh v Zakavkaz'e.

3 I. L.S. Sobosinskej, Persiia (St Petersburg, I913), pp. 288-289. 


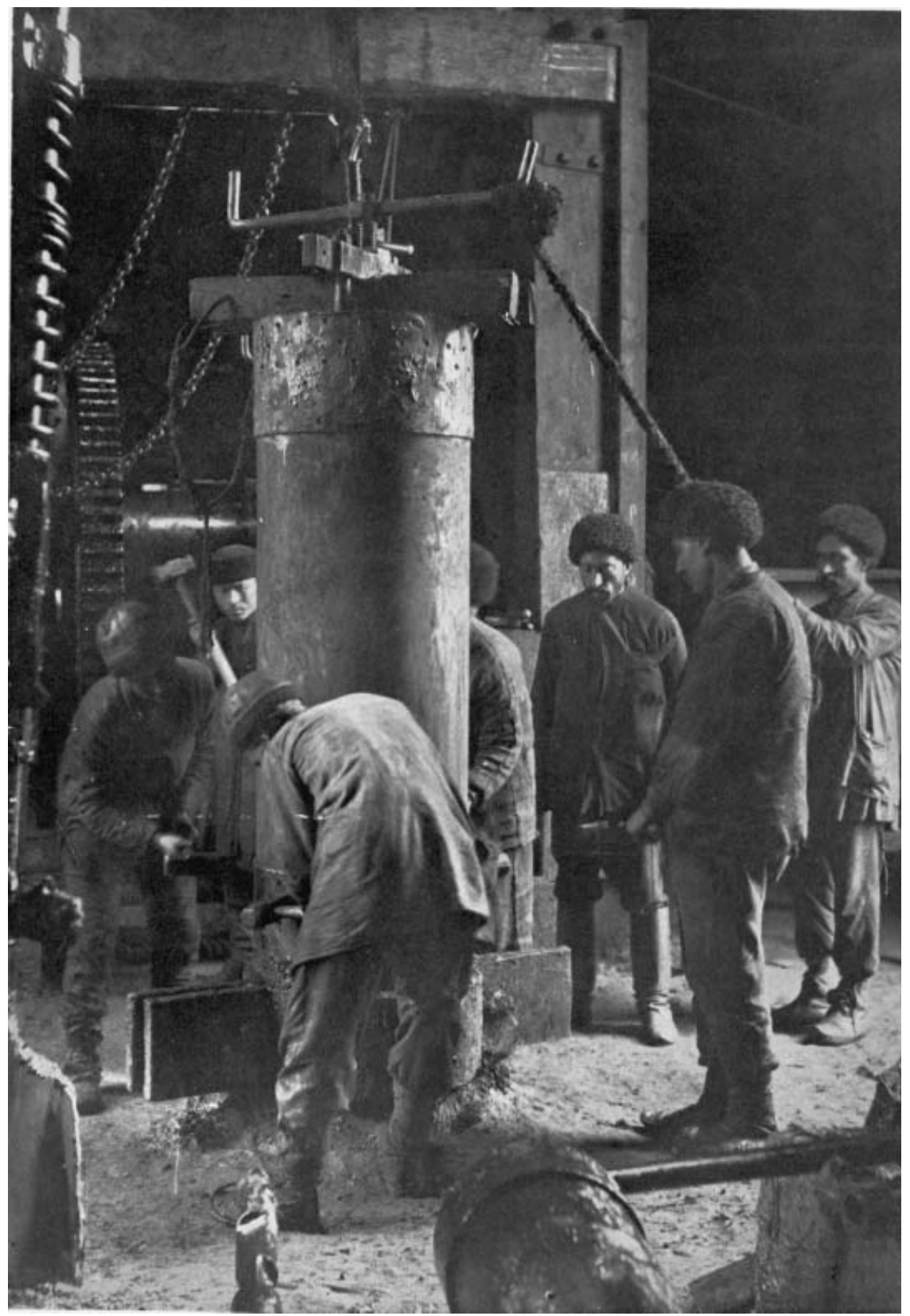

Figure 2. Iranian workmen riveting casing in a Baku oil well.

From: Beeby Thompson, The Oil Fields of Russia and the Russian Petroleum Industry, facing p. 190. 


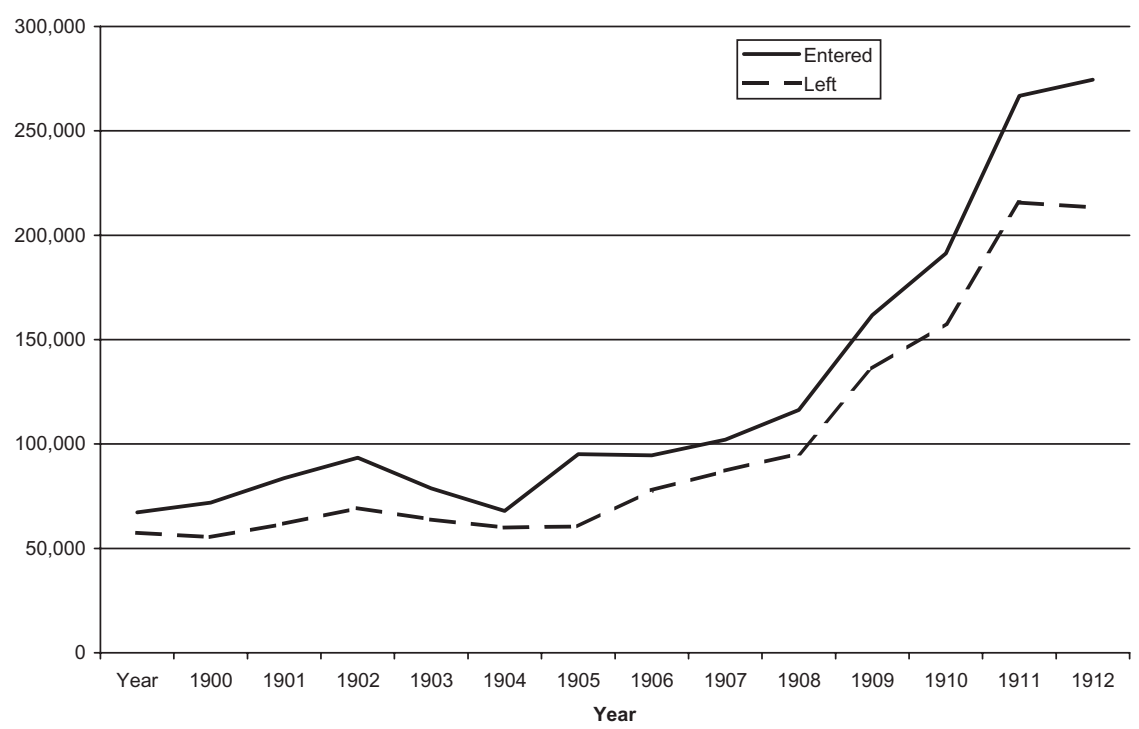

Figure 3. Legal migration of Persians to Russia, I900-1913

Source: Marvin L. Entner, Russo-Persian Commercial Relations, I828-1914 (Gainesville, FL, 1965), p. 60.

amongst those residing in the border regions, then the actual number of Iranian migrants must definitely have exceeded the recorded figures. Moreover, crossing the border illegally allowed poor migrant workers to avoid paying a range of fees imposed discriminatorily on them. These fees included the costs of "visas", "passing the gate", a "donation to charitable organizations", and of helping various projects such as the "Russian railroad projects". ${ }^{2}$ The same fate awaited them on their return to Iran. The Iranian border guards and custom officers refused to let the returnees pass until they had parted with much of their savings. ${ }^{33}$ Ardabil and its vicinity was the main region sending illegal migrant labourers to Russia. According to Ilinski, the number of illegal migrants from this region was more than 20,000 a year. ${ }^{34}$ Tigranov puts the figure at 30,000 to 40,000 per year. ${ }^{35}$ In April I 897 Kaspii, a newspaper, reported that "lately every ship coming from Persia to Baku carries some iso to 200 Persian subjects,

32. RASCA, record 45, dossier I, file I49, pp. 68-69.

33. Molla Nasreddin, 6 (1906).

34. G.N. Ill'inskii, "Agrarnie otnosheniia v Irane v kontse XIX - nachale XX veka”, v Uchenie zapiski In-ta Vostokovedniia Akademii Nauk SSSR, 8 (1953), p. I 20.

35. L.F. Tigranov, Iz Istorii obshchestvenno-economicheskikh otnoshenii Persii (St Petersburg, I905), pp. I59-160. 
illegally entering the Caucasus to seek work." ${ }^{6}$ Strigunov argues that by the turn of the century the number of illegal workers in Baku province had reached I $8,000.37$

Seasonal workers comprised the mainstream of the labourers crossing the frontier. Returning home after harvest to avoid the cold winter of the Caucasus, they worked some seven to eight months of the year on the cash-crop plantations. For example, in 1900, while 67,304 Iranian workers crossed the Russian frontier legally, 57,489 returned to Iran. In I 906 these figures reached 95,1 32 and 60,524 respectively, and 274,555 crossed into Russia while 213,373 returned in 191 $3 .{ }^{38}$ Nevertheless, the process of migration to Russia was so entrenched that Iranian emigrants constituted a large labour force in the region. On the eve of the Russian Revolution of I905 the Baku oilfields employed some I0,000 Iranian workers, ${ }^{39}$ and in the copper mines and industrial plants of Alaverdi in the north of Yerevan there were 2,500 Iranian workers, who accounted for 70 per cent of total employees there. In the other industries in the Caucasus and Central Asia, Iranian workers constituted 30 per cent of all labourers and they were the largest of the foreign groups residing there. In the city of Tbilisi, the number of Iranian labourers reached 5,000 by $1910.4^{\circ}$

The steadily growing number of migrant workers in the southern part of Imperial Russia was halted by the political upheavals following the Russian Revolution of 1905. For example, in January 1906 the total number of workers employed by 75 oil companies operating in the

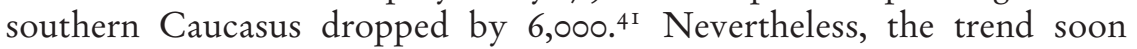
changed again, due first to the Constitutional Revolution in Iran and also to the political stability in the Tsarist Empire. In I907 the Caucasus and Central Asia witnessed a massive influx of Iranian migrant subaltern. Thousands of poor peasants from Persia's northern provinces of Azerbaijan and Khorasan crossed the frontier seeking a job..$^{42}$ According to Wladikavkaskaia railway documents, during the three days of I 2, I 3 and I4 September I 907 I, 500 labourers arrived in Baku. ${ }^{43}$ In the same year the number of workers in Baku's oil and other industries returned to its earlier level of $50,000.44$

\footnotetext{
36. Kaspii (April i 897).

37. I.V. Strigunov, Iz storii formirovaniia Bakinskogo proletariata (Baku, I960), p. I34.

38. RGSCA, record I 3 , dossier 23 , file 745 , p. I.

39. Belova, "Ob otchodnichestve iz severozapadnego Irana", p. I 17.

40. RGSCA, record I 3 , dossier I, file 267 , p. I4.

4I. I.M. Rasanova et al. (eds), Azerbaidzhan v gody pervoi russkoi revoliutsii, sbornik statei

(Baku, I966), p. 95.

42. Baku, 42 (1907).

43. Bakinskoie ekho, 16 (1907).

44. Strigunov, Iz istorii formirovaniia Bakinskogo proletariata, p. I34.
} 


\section{GENDER, ETHNICITY AND AGE OF THE IRANIAN SUBALTERN}

Although the available data on Iranian migrant workers do not provide an inclusive picture of the gender composition of Persian migrant workers, nevertheless by comparing two sets of data derived from the first national census of the Russian Empire carried out on 28 January i 897, we can derive a sketchy picture of gender divisions amongst Iranian migrants in the late nineteenth-century Caucasus and Central Asia. Table I overleaf shows the number of women at work in the city of Baku and its fringes. At 8.6 per cent, the textile industry was the largest employer of women; as a whole, women accounted for no more than 2.5 per cent of total workers in I 897 .

Concerning the total number of Iranians living in the Russian Empire, the first national census of 1897 divided the community into two categories. The first group comprised those who spoke Persian but did not hold Iranian nationality. They had been residing in the region for centuries and formed a solid community, especially in the big cities. The second group, known as the Iranian subjects, consisted mostly of newly arrived migrant workers. However, while the national census considered the gender dimension of both groups and noted that women constituted some 20 to 25 per cent of the total number of Iranian migrants living in the Caucasus and Central Asia, it did not explain what percentage of these Iranian women worked in industry.

Although Table 2 overleaf demonstrates the gender composition of Iranian migrants, we do not - as noted earlier - know what percentage of these women went to work outside the home. The only available information on Iranian women workers is for a later period and covers just Baku's oil industry. In an article published in I926, Irandoust (his real name was V.P. Ostrov) argued that of the 22,840 Iranians working in the Baku oil industry at the beginning of the twentieth century 8.3 per cent were women. By 1920 they accounted for 7.7 per cent of a total of 24,958 Iranian workers. ${ }^{45}$

There were obvious cultural barriers making it improbable that Iranian women of the nineteenth century could leave their locality in pursuit of work across the border. The farthest they could travel in search of work was to provincial centres or the country's capital, where they were mainly engaged in the domestic sector or carpet-weaving industry. The seasonal migrants were mainly composed of male subaltern. However, considering the working traditions in the region, one could assume that working in the domestic sector and carpet-wavering industry was widespread amongst the female members of Iran's non-seasonal working families. 
Table I. Women in work, Baku and suburbs (I 897)

\begin{tabular}{lccc}
\hline Branches of Baku industries & $\begin{array}{c}\text { Total number of } \\
\text { workers }\end{array}$ & $\begin{array}{c}\text { Female } \\
\text { workers }\end{array}$ & $\begin{array}{c}\text { Percentage of } \\
\text { females }\end{array}$ \\
\hline Mining & 4,557 & 12 & 0.3 \\
Chemical & 1,029 & 8 & 0.8 \\
Metal & 2,892 & 15 & 0.5 \\
Wood & 539 & 10 & 1.9 \\
Textiles & 755 & 65 & 8.6 \\
Dairy products & 203 & - & - \\
Processing minerals & 123 & 6 & 4.9 \\
Food & 958 & 49 & 5.1 \\
Printing & 147 & 4 & 2.7 \\
Construction & 3,161 & - & - \\
Railways & 1,136 & 22 & 1.9 \\
\hline
\end{tabular}

Source: Strigunov, Iz istorii formirovaniia Bakinskogo proletariata, p. I 38.

Table 2. Gender composition and geographical distribution of Persian speakers and Persian subjects in the Caucasus and Central Asia (I897)

\begin{tabular}{lrrrc}
\hline Regions \& cities & Male \& female & Male & Female & $\begin{array}{c}\text { Percentage of } \\
\text { females }\end{array}$ \\
\hline Caucasus & $\mathbf{7 1 , 4 3 2}$ & $\mathbf{5 4 , 6 8 7}$ & $\mathbf{1 6 , 7 4 5}$ & $\mathbf{2 3 . 4}$ \\
Baku & 29,941 & 22,012 & 7,929 & 26.5 \\
Tbilisi & 10,133 & 7,749 & 2,384 & 23.5 \\
Yerevan & 8,458 & 5,239 & 3,219 & 38 \\
Elizabethpol & 13,014 & 8,391 & 4,623 & 35.5 \\
Dagestan & 3,571 & 2,582 & 989 & 27.7 \\
Central Asia & 23,191 & $\mathbf{1 8 , 4 5 5}$ & 4,736 & 20.4 \\
Trans-Caspian & 16,914 & 14,059 & 2,855 & 16.9 \\
Samarqand & 2,915 & 2,390 & 525 & 18 \\
Sir Darya & 1,661 & 1,031 & 630 & 37.9 \\
Farqaneh & 2,254 & 1,565 & 689 & 30.6 \\
\hline
\end{tabular}

Sources: Arabadzian and Kuznetsova, Iran. Sbornik Statei, pp. I95-2 I4, and Hassan Hakimian, "Wage Labour and Migration: Persian Workers in Southern Russia, I 880I9I4", International Journal of Middle East Studies, I7 (1985), p. 445.

We have useful data on the ethnic composition of the workforce in the Baku oilfield. Unfortunately, there are no comparable data available that provide as clear a picture of the ethnic composition of migrant workers in labour-intensive industries in other regions of the Caucasus. In the case of the Baku oilfield, Iranian workers constituted the majority of unskilled foreign workers in the region. According to Thompson, who visited the region in the early twentieth century, "the daily work on the properties, such as cleaning the setting tubs, chutes, etc., was done exclusively by Persians". ${ }^{6}$ The labour 
Table 3. Ethnic composition of the workforce in the Baku oilfield ( 1893 and I900)

\begin{tabular}{lcccccc}
\hline Ethnic origin & \multicolumn{3}{c}{1893} & & \multicolumn{2}{c}{1900} \\
\cline { 2 - 3 } \cline { 5 - 6 } & $\begin{array}{c}\text { \% of unskilled } \\
\text { workers }\end{array}$ & $\begin{array}{c}\text { \% of skilled } \\
\text { workers }\end{array}$ & & $\begin{array}{c}\text { \% of unskilled } \\
\text { workers }\end{array}$ & $\begin{array}{c}\text { \% of skilled } \\
\text { workers }\end{array}$ \\
\hline Local Tatars(Azeris) & 21.5 & 3 & & 19 & 12.3 \\
Russians & 13.7 & 54.3 & & 10.9 & 42.9 \\
Armenians & 26.4 & 27 & & 24.3 & 30.8 \\
Dagestanis & 19.1 & 1 & & 17 & 2.8 \\
Iranians & 14 & - & & 24.7 & 4.7 \\
Others & 5.3 & 14.7 & & 4.1 & 6.5 \\
\hline
\end{tabular}

Source: Strigunov, Iz istorii formirovaniia Bakinskogo proletariata, pp. I43-I45.

market in the Baku oilfield was initially segmented by race, with oil companies hiring mainly Russians and Armenians for jobs requiring skill and literacy, and Muslim workers, Iranians, local Tatars and Dagestanis for lower-paid unskilled jobs. However, as the result of a policy of favouring the empire's local Muslims the unskilled job sector was gradually allocated exclusively to migrant workers, the main group amongst them being the Iranians. By sustaining traditional barriers between migrant and nonmigrant groups on the shop floor, these hiring practices not only averted labour conflict but also pushed the migrant worker to the margins of society.

Furthermore, this labour discrimination went beyond segregation in employment policy. As we shall see in what follows, employers perpetually discriminated in terms of wages too. For identical work, different wages were paid based mainly on the workers' nationality. Even for skilled jobs, Iranian migrant workers earned less than Russians, Armenians, and even less than local Muslim workers. ${ }^{47}$ It is noteworthy that, contrary to what one might expect, the prevailing shortages of unskilled workers and the incessant demand for migrant labour did not alter employment conditions in favour of the latter group. Nor did they exclude ethnic discrimination in the form of professional segregation.

Concerning the data presented in Tables I to 3, one should realize, as Hakimian has pointed out, that since the national census was conducted in January,

[...] it is clearly seasonably biased as it excludes all those people who returned home in the cold months of Winter. Moreover, it does not include all working branches, especially those traditionally engaging women workers, such as 
Table 4. Age Distribution of Workforce in Baku District (I 897)

\begin{tabular}{lccrrrrrc}
\hline $\begin{array}{l}\text { Branches of } \\
\text { Baku industries }\end{array}$ & $\begin{array}{c}12 \text { or } \\
\text { less }\end{array}$ & $13-14$ & $15-16$ & $17-19$ & $20-39$ & $40-59$ & $60+$ & Unknown \\
\hline Mining & 0.2 & 1.0 & 4.0 & 12.0 & 73.0 & 8.6 & 1.1 & 0.1 \\
Chemicals & 0.6 & 1.1 & 3.1 & 8.4 & 72.6 & 12.8 & 1.4 & - \\
Metal & 2.6 & 4.0 & 7.3 & 13.0 & 62.0 & 10.0 & 1.0 & 0.1 \\
Wood & 2.2 & 5.4 & 10.8 & 11.1 & 53.1 & 15.9 & 1.5 & - \\
Textiles & 5.3 & 2.8 & 7.0 & 8.2 & 52.3 & 19.0 & 5.3 & 0.1 \\
Dairy products & 4.9 & 1.0 & 9.4 & 17.7 & 53.2 & 10.9 & 2.9 & - \\
Processing & 0.8 & 0.8 & 2.4 & 4.9 & 68.3 & 17.9 & 4.1 & 0.8 \\
minerals & & & & & & & & \\
Food & 3.6 & 2.2 & 4.8 & 10.3 & 57.4 & 17.1 & 4.4 & 0.2 \\
Printing & 3.4 & 8.8 & 7.5 & 21.1 & 54.4 & 4.1 & - & 0.7 \\
Construction & 1.2 & 1.6 & 3.7 & 8.3 & 53.2 & 26.8 & 5.1 & 0.1 \\
Railways & 0.1 & 0.5 & 0.5 & 3.1 & 77.5 & 17.7 & 0.6 & - \\
\hline
\end{tabular}

Source: Strigunov, Iz istorii formirovaniia Bakinskogo proletariata, p. I 34 .

domestic work. Besides the high incidence of illiteracy coupled with the illegalalien status of many Persians could make a strong case for possible underestimation of the final results..$^{8}$

Child labour is another issue that deserves attention. According to the I 897 Russian national census, the age composition of Baku's workforce was as in Table 4. In a study on the living conditions of Iranian subaltern on the margins of Tsarist Russia, Bahram Agayev, a member of the Iranian migrant community in the Caucasus, presents a devastating account of the children taken by a mediator (pochtalion) who had been touring Iranian villages in the northern provinces in order to recruit children for the Caucasus industries.

Pocbtalyon recruited children by promising to pay their parents 40 roubles per year. In each tour, after recruiting about roo children, the pochtalyon made them walk to Baku. The journey took 7 to 8 days. During the journey, the pocbtalyon provided no food and the children had to collect their food from the villages on the road. On arrival, they were assembled in "common houses" and were carefully checked and chosen by visiting tradesmen who eventually paid an average of 100 roubles per child to pochtalyon. 49

In I90I, 44.7 per cent of workers engaged in tobacco production were aged I 5 or I6. The figure for the printing industry for the same year was 32.2 per

48. Hassan Hakimian, "Wage Labour and Migration: Persian Workers in Southern Russia, I880-1914", International Journal of Middle East Studies, I7 (1985), p. 446.

49. Republic of Azerbaijan Archive of the History of Political Parties and Social Movements [hereafter, RAAHPPSM], record I 53, dossier I, file 78. pp. $2-3$. 
cent; this compares with 7.5 per cent for 1897 , which implies a rapid increase of 429 per cent. ${ }^{\circ}$ Moreover, the average wage of the children was a half or as little as one-third that of adult workers. ${ }^{\text {II }}$

\section{THE WORKING AND LIVING CONDITIONS OF IRANIAN SUBALTERN}

The Iranian migrant workers consisted for the most part of common labourers taking simple manual jobs in the Caucasus and Central Asia. They can be divided into four categories: agricultural labourers receiving wages; agricultural labourers paid in kind with crops (ranjbar); porters or dockworkers; and industrial labourers (mozdur). According to a report compiled by the governor of Elizabethpol, "certain categories of hard and dirty jobs were exclusively carried out by the foreign labourers". These included "cleaning the water channels affected by malaria, [working on] rice plantations, cotton-picking and sulphating grapes". ${ }^{2}$

Furthermore, Belova indicates that in Elizabethpol it was almost exclusively the Iranians who worked on the agricultural land. Every year, thousands of Iranians migrated to this province to take up occupations normally refused by local workers because of the inferior pay and conditions. ${ }^{53}$ Here, a comparison with the segregation policy imposed on black labourers in the American South is illuminating. In his study of the labour market in the American South during the segregation era Michael Honey points out that:

[In the I930s] occupational segregation remained as evident in the factories as in the crafts. Wherever they worked, the racial barriers imposed on them by white society insured that the better paying positions went to white males. While white males worked as mechanists, superintendents, inspectors, mechanics, repairmen, and in product finishing, black men swept floors, lifted and hauled materials, or did semi-skilled fabricating and production work. 54

In a report on migrant workers published in 1900 in the Saratovski viestnik newspaper, the author asserted that throughout Russia Iranian workers consistently took on the heavy work. He referred, for example, to the port of Astrakhan, where the dockworkers were exclusively Iranian. 55

50. Ibid., record 509, dossier I, file 68, pp. I, 8. Strigunov, Iz istorii formirovaniia Bakinskogo proletariata, p. I 39 .

5. Ibid., p. I 38 .

52. RGSCA, record I 3 , dossier I, file 267 , p. i4.

53. Belova, "Ob otchodinichestve iz severozapadnego Irana", p. i I 5.

54. Michael Honey, "Racism and the Labor Market in the American South: Memphis, Tennessee in the Segregation Era", in Marcel van der Linden and Jan Lucassen (eds), Racism and the Labour Market (Berne, 1995), p. 225.

55. Strigunov, Iz istorii formirovaniia Bakinskogo proletariata, pp. 88-89. 
The living conditions of these dockworkers were extremely poor. In an article published in Taraqqi in I9II, Mohammad Amin Rasulzadeh portrayed their deprived state:

The Iranian workers in the Caucasus were working the hardest and meanwhile they were the poorest workers in the Caucasus. They worked is to I 8 hours a day - sometimes even at night. The daily average wage of the dockworker hamshabri was 50 to 60 kopeks. Their earnings were some 20 per cent less than the average earnings of the other simple wage labourers. They ate badly and often Io to Is of them shared one room, paying 50 kopeks per month for it. These rooms, which looked like stables, lacked very basic and essential hygiene. ${ }^{56}$

An official survey of the living conditions and earnings of foreign labourers in the Caucasus compiled by Russian officials estimated that, on average, Iranian labourers in the region earned some 25 per cent less than local workers. ${ }^{7}$ Furthermore, according to the same survey, a large number of seasonal workers were unable to cover the cost of accommodation and had no other option than to sleep in the open air, under bridges or along walls. ${ }^{58}$ Having to survive on a staple diet of bread, cheese, and onions, the majority of these workers suffered from malaria, syphilis, or diarrhoea.59 According to another eyewitness account, the Iranian labourers survived "on the simplest and meanest of diets, their food being almost exclusively confined to bread and, in the proper season, raw cucumber, watermelons, grapes, etc., when sufficient may be purchased for a kopek or two to last a day". ${ }^{60}$ The living conditions of nonseasonal workers were no better either. After working a I 2 to I8-hour day, mineworkers gathered in wooden barracks known as artel, which accommodated an average of 100 workers and had no sanitary facilities. ${ }^{6}{ }^{1}$

The various reports compiled by the Iranian consulates in Baku, Ganje, and Tbilisi also portray the outrageous working and living conditions of these workers. For the dockworkers, the decayed and rotten docks usually caused hundreds of them to drown. ${ }^{62}$ Working conditions in the oil sector were no better. According to one of these reports:

In Baku's district of Sabunchi and Balakhani the private holders of the oil wells employ exclusively Iranian well diggers. In this region, in order to reach oil the depth of the wells varies between 35 and 45 metres. Usually, after 30 metres of

56. Mohammad Amin Rasulzadeh, Gozaresh-ha'i az Enqelab-e Mashruteh, tr. Rahim Reisnia (Tehran, I998), p. 78.

57. RGSCA, record I 3 , dossier I, file 267 , p. I6.

58. Ibid.

59. RAAHPPSM, record I 53 , dossier I, file 78, p. 3 .

60. Beeby Thompson, The Oil Fields of Russia, p. 376.

61. RAAHPPSM, record I 53 , dossier I, file 78, p. 3 .

62. Archive of the Ministry of Foreign Affairs, Tehran [hereafter, AMFA], B. I 2, D. 32, I910, B. I3, D. 5I, I9I2. 
digging, the ill-fated Iranian workers cannot stand the gas inside and are poisoned and pass away. No information on working condition is available, and with no knowledge of what awaits them at the bottom of the well the Iranian diggers accept the pay of 20 to 40 manats a day and meet their unfortunate fate. It is almost every day that news of the death of 4 or 5 of these diggers appears in the local press. ${ }^{6}$

According to a different source, the job security of the Iranian workers was extremely limited.

Very few had permanent jobs, and even the oil workers in Baku were no exception to this. Under a 1903 law, employers no longer had any responsibilities for accidents involving foreign workers. Moreover, the economic and political insecurity of foreign workers was further dramatized when, following the I905 labour unrest throughout Baku, the Russian authorities forced the extradition of thousands of them. ${ }^{64}$

The first-recorded news of protest amongst Iranian workers was of the three-day strikes in 1903 in the tobacco factory of Mirzabekianc. The strike was launched exclusively by Iranians, who composed one-quarter of the 800 workers at this factory. There are no records of other workers taking part. During the strike, leaflets in Persian were distributed, listing workers' demands. ${ }^{65}$ It is not known where these leaflets were published. In his masterpiece Tarikh-e Mashruteh Iran [History of the Iranian Constitution], Kasravi refers to a customs employee in Julfa called Bakhsh'ali, who passed revolutionary literature across the border with the Caucasus. ${ }^{66}$ Two years later, in I905, 700 Iranian workers in the copper mines of Alaverdi in the north of Yerevan instigated a strike. Iranian miners accounted for 2,500 of the 3,000 to 4,000 miners there. ${ }^{67}$

Amongst the twenty-eight points of their demands, were shorter working hours (a seven-hour day), a 20 per cent increase in wages, and better working conditions. As a result of the mediation of the Iranian consulate, the workers dropped their call for a wage increase, while insisting, however, on their other demands. ${ }^{68}$ After almost five months, the governor general of the Caucasus crushed the strike by dispatching military forces to the region. Twenty-nine miners were killed, and all

63. AMFA, B. I3, D. 34, I9I 2.

64. Hakimian, "Wage Labour and Migration", p. 450.

65. S.M. Aliev, "K voprosu o sviaziakh Bakinskogo I Tiflisskogo komiteta RSDRP s Iranskimi revoliutsionerami v I903-191 I", in Slavnie stranitsy bor'by $i$ pobed. Mat-y nauchnoi sessii, posviashchnnoi 6o-letiiu II s'ezda RSDRP I vseobshchikh zabastovok v Baku i na inge Rosii letom 1903 g. (Baku, I965), p. 192.

66. Ahmad Kasravi, Tarikh-e Mashruteh Iran (Tehran, 1978), p. I I.

67. Revolutionary Movements in Armenia 1905-1907: Collection of Documents (Yerevan, 1955), p. i85. See also Nor Khosk, 6 (1906).

68. AMFA, B. 7, D. 5, 23 April i905. 
the Iranian miners were arrested and later deported to Iran. ${ }^{69}$ Following the Alaverdi strike, the Tsarist police became more concerned about the activities of Iranian migrant workers and, according to some secret reports, on more than one occasion Iranian labour militants charged with initiating labour unrest were arrested and expelled from Russia. ${ }^{70}$

\section{CRAFTING A POLITICAL CONSCIOUSNESS}

Since the early days of their mass migration to Russia, the Iranians had endeavoured to establish a set of connections bringing them together. The first attempt involved setting up Persian schools. In Baku, they founded Ettehad in the city centre, and Tamadon in the Sabunchi district. The activities of these schools went beyond conventional education for migrant children. They were soon turned into a cultural club were the migrant Iranians could assemble and discuss social issues. The Ettehad School, for example, had an active association called the Sanduq-e Ta'avon-e Madreseh-e Ettehad-e Iraniyan-e Baku [Cooperation Fund of the Iranian Ettehad School in Baku], which held weekly meetings. ${ }^{7 \mathrm{I}}$

The political upheavals that followed Russia's defeat in the RussoJapanese War of 1904- I905 and the Iranian Constitutional Revolution of I905-I9I I also altered the political environment for the Iranian migrant subaltern. The southern Caucasus, which had links with the Russian social-democratic network, hosted a leading community of Iranian political activists and offered exceptional shelter to Iranian political groups for their headquarters. Alongside the local branches of all-Russian political parties and organizations, the Iranians too established their own parties and societies. The most important of the political organizations were Ferqeh-ye Ejtema'iyun Amiyun-e Iran [Social Democratic Party of Iran], founded with the help of the social democratic group of Caucasian Muslims (Hemmat) in $1904 ;^{72}$ Ferqeh-y Ejtema'iyun-Enqelabiyun [Social Revolutionaries Party]; 73 Hezb-e Demokrat-e Iran [Iranian Democrat Party]; Hezb-e Adalat [Adalat Party], which later adopted the name "Communist Party of Iran"; Jam'iyat-e Ma'aref-e Iran [Iran’s Knowledge

69. Ibid., pp. 193-196. See also S. Shaumian, "Failed Strike", Nor Khosk, 6 (1906). At the Fifth Congress of the RSDRP (1907) Shaumian presented a detailed report on the Alaverdi strike. See S. Shaumian, Collected Works, vol. I (Moscow, I957), p. 236. In articles published in Kavkozkii rabochii listok, 3 (1905), Jalil Mohamad Qolizade also presented a detailed account of the strike and the fate of those Iranian miners deported to Iran.

70. RAAHPPSM, record $\mathrm{I}_{3}$, dossier 27 , file 533 , and record I 5 , dossier I, file 78 .

7I. Ibid.

72. S.M. Aliyov, People of Asia and Africa, (Moscow, 1965).

73. Salmollah Javid, Iran Sosyal Demoktar (Adalat) Firqasi Haqina Khataralarim [mimeo] (Tehran, I980), p. I I. 
Society], a front for the Adalat Party; and Hezb-e Esteqlal-e Iran [Iran Independent Party], a pro-Iranian government party. ${ }^{74}$

Following its formation, the Adalat Party launched a widespread campaign amongst the Iranian subaltern. The dominant egalitarianism inspired by the Russian Revolution of I9I7 affected many Iranian subaltern. It was during this period that Adalat Party activists occupied the Iranian consulate in Baku. They made a series of demands, including the abolition of a special annual tax each individual migrant worker had to pay to the consulate. They also called for a permanent delegate at the Iranian consulate to be responsible for migrant affairs. ${ }^{75}$ The Iranian consulate eventually conceded to the protestors' demands, and migrant workers chose Asadollah Qaffarzadeh, a veteran social democrat, as viceconsul in Baku. ${ }^{76}$

Concerning the non-Iranian political parties, the approach of the Iranian migrant workers was twofold. While they remained reluctant to join local leftist organizations, they took a blunt stand against the nationalism gradually gaining ground in the region. Creating a Greater Azerbaijan bringing together the Azeris on both sides of the Araxes - was the main aim of the Caucasian Azeri nationalists. Since the majority of Azerispeaking people lived in a large region within northern Iran, the nationalists' ultimate hope was to persuade the Azeris of Iran to support their proposed project for unity. To achieve their ultimate goal, they regarded the Iranian migrant Azeris as one of the main target groups for their political propaganda and recruitment. According to Sa'ed Maraghe'i - the Iranian consul in Baku - there were some 70,000 Iranians living in Baku during World War I,77 and amongst them the Azeris from Iran's Azerbaijan province were the titular ethnic group.

With the fall of the Tsarist regime in October 1917, the Caucasian nationalists dispatched an emissary to Tabriz, urging local politicians to secede from Iran and join with Baku to form a great federation. However, the Iranian Azeris rejected their proposal. ${ }^{78}$ Following their failure to convince the Iranian Azeris to join an independent federation, in January I9I 8 the nationalists published an editorial in Achiq Söz [Candid Speech], the main periodical of the local Azeri nationalists, which directly tackled the question of Iranian Azerbaijan. In a rather haughty style, the editorial defined the historical boundaries of Azerbaijan as stretching to the

74. Ibid.

75. Mohammad Sa'ed Maragheh'i, Khaterat-e Siyasi (Tehran, 1994), p. 59.

76. Cosroe Chaqueri, The Soviet Socialist Republic of Iran, 1920-I92 I (Pittsburgh, PA, I995), p. I 54 .

77. Ibid., p. $4^{8}$.

78. British Foreign Office, FO 371/4358, I918. 
Caucasian mountains in the north and to the central Iranian city of Kermanshah in the south, with Tbilisi forming the western frontier and the Caspian Sea the eastern frontier. The Russian expansionists and Iranian ruling class were blamed for having adopted policies that resulted in the dismemberment of the nation of Azerbaijan. Furthermore, according to the author, it was the "natural right of the southern Caucasian Muslims to call their territory Azerbaijan" and to hope that "one day their brothers in the south could join them". ${ }^{79}$

Interestingly enough, the first reaction to Achiq Söz's stance came from Iranian Azeri migrants in the Caucasus. In their perception the view expounded in the editorial of Achiq Söz was nothing less than a nationalist plot, which menaced Iran's sovereignty and territorial integrity. Though speaking the same language as the people of their adopted country, the Iranian Azeris nevertheless remained a self-contained community with a distinctive identity as migrant subaltern. In terms of social ties they were closer to other non-Azeri Iranians than to local Azeris. Their political ties were mainly with Iranian leftist organizations and, above all, with the Iranian Democrat Party. The Caucasian branch of the Democrat Party was founded in I9I4 and its members were recruited from migrant subaltern groups living in Baku and the border district. During World War I, the local branch of the Democrat Party became the most high-profile and active organization amongst Iranian migrant workers.

With the escalation of nationalist activities in the Caucasus, the Democrat Party gradually adopted a defensive stand against the propaganda initiated by local Azeri nationalists. Disturbed by the nationalist stance of Achiq Söz, the Iranian Democrats initiated a political campaign in the region and on Io February I91 8 launched a bilingual newspaper, Azarbayjan, Joz'-e la-yanfak-e Iran [Azerbaijan, an Inseparable Part of Iran]..$^{80}$

In addition to promoting political change and reform in Iran, the newspaper declared its task to be one of "displaying Iran's glorious past

79. Achiq Söz, I7 January I918.

80. Mohammad Khan Tarbiyat was founder of the Democrat Party's Baku committee. He was also director of the Iranian Ettehad school in Baku. The committee's other members included Mirza Mahmud Khan Parvarish, Mitza 'Abdollah 'Abdolahzadeh, Shaykh Baqir Shirazi, Azhdar 'Alizadih, Hosayn Khayat, Hosayn Mahmudzadeh, Mir Hosayn Motazavi, Mirza 'Aliqoli (from Ashgabat; he later became the editor of Azarbayjan, Joz'-e la-yanfak-e Iran), Mir Jafar Javadzadeh Pishavari, Haji Mo'alim Ja'farzadeh Kalkhali, Mirza Aqa Valizadeh, Sayfollah Ibrahimzadeh, and 'Ali Akbar Osku'i (founder of the Iranian guild and a member of its executive committee). Parvarish had to leave Baku in I916 on account of his political activities. He left illegally for Iran. After the Russian Revolution of February 1917, the Democrat Party began to operate legally. See Javid, Iran Sosyal Demoktar (Adalat) Firqasi Haqina Khataralarim, pp. 9-10. 
and its historical continuity", ${ }^{81}$ as well as of "hindering any attempt to diminish the national consciousness of Iranians" ${ }^{82}$ Similarly, it contended that Azerbaijan shared a history with the rest of Iran, and strove to foster self-confidence and a sense of belonging to territorial Iran. While glorifying the name of Azerbaijan and its "key position in Iranian history", the newspaper frequently referred to "the many centuries during which Azerbaijan governed all of Iran". Pointing to the geographical front-line position of the province, the newspaper "declared it to be the duty of Azeris" to confront the hostile outsiders and to safeguard Iran's "national pride" and "territorial integrity".

With a persuasive political agenda, Azarbayjan, Joz'-e la-yanfak-e Iran pursued what it had proclaimed in its first issue to be its duty, and continued to publish even after the early takeover of Baku by the Bolsheviks. However, it was forced to close down in May 191 8 when the Musavatists - the local nationalists - regained power and formed a national government. Subsequently, all Iranian societies were dissolved. ${ }^{83}$

\section{CONCLUSION}

In narrating the history of the Iranian subaltern community in the Caucasus, I have endeavoured to depict a migrant community formed within the boundaries of prevailing pre-capitalist relationships. The absence of individualism and equality before the law, which manifested itself in second-class citizenship for these Iranians, was one characteristic of such relationships, which drove them towards an alternative identity as a means of protection. The majority of this community were Iranian Azeris who, while in Iran, were considered an ethnic minority; in their host country they lived largely amongst their co-ethnic-linguistic group, the Azeris of the Caucasus. The persistence of inequality before the law created a bond between these migrant workers and also a sense of defensive territorial-Iranian commonality rather than ethno-linguistic or class solidarity with the native workers in their adopted country. ${ }^{84}$ Furthermore, by upholding their territorial-Iranian identity the Iranian subaltern community crafted a significant and unbroken link with a seminal past that could fill the vacuum between their origins and their actuality. ${ }^{85}$ As

8I. On the origins of reconstructing Iran's pre-Islamic history in the nationalist discourse, see Mohamad Tavakoli-Targhi, "Contested Memories: Narrative Structure and Allegorical Meaning of Iran's Pre-Islamic History”, Iranian Studies, I-2 (1996), pp. I49-175.

82. Azarbayjan, Joz'-e la-yanfak-e Iran, 2 and 3 (1918).

83. Javid, Iran Sosyal Demoktar (Adalat) Firqasi Haqina Khataralarim, pp. I4-I 5.

84. On the process of self-identification see Thomas Hylland Eriksen, Ethnicity and Nationalism: Anthropological Perspectives (London, 1993), pp. 9-10.

85. I. Gershoni, "Imagining and Re-imagining the Past: The Use of History by Egyptian Nationalist Writers, 1919-1952", History \& Memory, 2 (1992), p. 7. 
Nipperdey has remarked, for this migrant community territorial-Iranian solidarity provided the driving force in shaping their cultural identity and promoting their political actions. ${ }^{86}$ Crafting such an inclusive culture created a community defined by political loyalty and attachment to a territorial identity that took precedence over their other forms of loyalty, in particular their ethnic, linguistic and class loyalties. 